\title{
Tık Odakı Habercilik: Türk İnternet Haber Medyası Üzerine Bir İçerik Analizi
}

- Selahattin CAVUS

Doç. Dr. Aksaray

Üniversitesi

selahattincavus@aksaray.edu. tr ORCID ID: 0000-0003-

0774-9594

- Nurcan EDE

Arş. Gör. Aksaray

Üniversitesi

nurcanede@aksaray.edu.tr

ORCID ID: 0000-0002-4097-

8367

\section{ÖZET}

Bu çalıșmanın amacl, dijital haberciliğin etik sorunlarından biri haline gelen tık odaklı haberciliği, Türk haber medyast örneğinde inceleyerek, tık odaklı haberciliğin kullanım biçim ve yoğunluklarını belirlemeye yöneliktir. Araştırmada, Türkiye'de en fazla ziyaret edilen 5 haber sitesinin resmî Twitter hesaplart incelenmiştir. Veriler, NodeXL programı vasitastyla ilgili haber sitelerinin Twitter sayfalarından elde edilmiştir. 1-10 Haziran 2020 tarihleri arasinda toplam 9.525 tweet, tlk odaklı olup olmadiklarina göre sinıflandırllmış ve tık odaklı olduğu belirlenen toplam 3.386 haber, içerik analizine tabi tutulmuştur. Verileri siniflandırmak amacıyla Biyani ve arkadaşları tarafindan 8 başlikta ele alınan tık odaklı haber kategorileri kullanılmıștır. Buna göre yayımlanan her 3 haberden biri tık odakl olacak şekilde üretilmiştir. Kategorilere göre; Merak Uyandırma ilk sirada yer alırken, bu kategoriyi sirasiyla Belirsiz Bırakma, Abartma, Tahrik Etme, Yazlyı Biçimlendirme, Canlandırma, Sağ Gösterip Sol Vurma ve Yanlış Bilgi verme takip etmektedir. Haber siteleri daha fazla tık alabilmek adına kasitl biçimde üretilen aldatıcı ve düşük kalitedeki içeriklere yer vermekten çekinmemektedir.

Anahtar Sözcükler: T1k Odaklı Haber, T1k Tuzağı, Gazetecilik, Yeni Medya, Etik 


\section{Click-Based Journalism: A Content Analysis on Turkish Internet News Media}

\section{- Selahattin CAAVUS}

Assoc. Prof. Aksaray

University

selahattincavus@aksaray.edu. tr ORCID ID: 0000-0003-

0774-9594

- Nurcan EDE

Res. Ass. Aksaray University nurcanede@aksaray.edu.tr ORCID ID: 0000-0002-40978367

\begin{abstract}
The aim of this study is to examine click-based journalism, which has become ethical issue of digital journalism, in the example of Turkish news media and to determine the usage forms and intensities of clickbased journalism. In the study, official Twitter accounts of the most visited five news portals in Turkey were examined. Data obtained from the Twitter pages of the relevant news portals through the NodeXL social network analysis tool. 9.525 tweets between 1-10 June 2020 were classified according to whether they were click-bait or not. 3.386 news determined to be click-based were subjected to content analysis. In order to classify the data, click-based news categories discussed in eight titles by Biyani et al were used. Accordingly, one out of every three news published was produced to be click-based. When the categories of click-bait news are examined, the category of Teasing takes the first place. This category is followed by Ambiguous, Exaggeration, Inflammatory, Formatting, Graphic, Bait-and-switch, and Wrong. News portals do not hesitate to use deceptive and lowquality content that is deliberately produced to get more clicks.
\end{abstract}

Keywords: Click-Based News, Click-Bait, Journalism, New Media, Ethics 


\section{GİRIŞ}

Gazeteciliğin temel ilkelerinden doğruluk ve dürüstlük; aracın niteliğine, türüne veya zamana göre değişim göstermez. Haber, yorum ve görüşleri içeren bilginin dolaşımını sağlamak kadar, bu ilkeler doğrultusunda toplumun sağlıklı bir yapıda kalması, gazetecinin önde gelen sorumlulukları arasındadır (Belsey \& Chadwick, 2011, s. 14). Bununla birlikte gazetecinin olayları dikkatli bir şekilde kontrol etmesi, bilindik kaynaklara bağlı olması, olayları tarafsız bir şekilde sunması, nokta sorular sorması ve en yüksek etik standartları benimsemesi gazeteci açısından değişmeyen ilkeler arasında yer almaktadır. Ancak gazetecilikte bazı şeyler kaçınılmaz biçimde değişmekte ve özellikle teknolojik ilerlemenin hemen her sektörü etkilediği gerçeğinden hareketle günümüzde gazetecilik ya da başka bir deyişle 'modern gazetecilik' önemli ölçüde dönüşüm geçirmektedir. Her şeyden önce, yeni medya ortamında yapılan gazetecilik faaliyetleri geleneksel gazetecilikten; haber toplama ve sunma, çoklu ortam (multimedya) içeriği başta olmak üzere bilgi depolama, dizinleme ve geri çekme, üretim ve editoryal süreçler, sunum, görüntüleme ve erişim bakımından teknik anlamda oldukça farklılaşmıştır (Pavlik, 2013, s. 287).

Yeni medya olarak da tanımlanabilecek ağ ve yazılım temelli medya eko-sistemi içerisinde, bir yandan gazetecinin ve gazeteciliğin imkânları gelişirken, diğer taraftan gazetecilik etiği bakımından yeni sorun alanları ortaya çıkmaktadır. Çevrimiçi platformlarda görülebilecek yanlış bilgi türleri arasında uydurma haberler, propaganda, komplo teorileri, asılsız ihbarlar, yanlı ya da tek taraflı haberler, söylentiler, ironi haberler ve tık tuzağı öne çıkmaktadır (Zannettou, Sirivianos, Blackburn, \& Kourtelli, 2019, s. 1-3). Ticari kaygılara eşlik eden bu tutum, günümüz dijital haber medyasına yönelik önemli bir tehdit haline dönüşmüştür. Haber sitelerinin ziyaret edilme sayılarını ve kullanıcıların haber sitelerinde bulunma sürelerini artırmak amacıyla kullandığg bazı yöntemlerin habercilik etiğgi bakımından sorun teşkil ettiği açıktır. Bu çalışmanın konusunu oluşturan 'tık odaklı habercilik' kavramını gazetecilik etiği ekseninde ele almak ve tık haberciliğinin yarattığı, ileride yaratabileceği sorunları göz önünde bulundurmak oldukça önemlidir. Dolayısıyla bu çalışmanın amacı, dijital haberciliğin etik sorunlarından biri haline dönüşen tık odaklı haberciliği, Türk haber medyası örneğinde inceleyerek, tık odaklı haberciliğin kullanım biçim ve yoğunluklarını belirlemeye yöneliktir. $\mathrm{Bu}$ amaç doğrultusunda, çalışmanın ilk bölümünde yeni medya ve gazeteciliğin değişen ve 
dönüşen uygulama biçimleri irdelenmiş, ardından tık haberciliğinin kavramsal çerçevesi çizilerek literatür taraması gerçekleştirilmiş ve son olarak Türk haber medyası örneğinde tık odaklı haber sunumuna ilişkin araştırmanın uygulanmasına yer verilmiştir.

\section{YENI MEDYA VE DEĞISSEN GAZETECILIIK PRATIKLERI}

Yeni medya kavramı; ağlar, kişisel bilgisayarlar vb.den oluşan çevrimiçi ve çevrimdış1 medyanın bir araya gelmesiyle ortaya çıkmıştır. Yeni medya, geleneksel medyadan farklı olarak, temelinde dijital kodlama sistemi olan, eş zamanlı, hipermetinsel ve multimedya özelliklerine sahip olan iletişim araçlarını tanımlamak üzere kullanılmaktadır (Van Dijk, 2004, s. 146). Yeni medya ile gazetecilik bir arada düşünüldüğünde, gelişen internet teknolojisinin geleneksel gazetecilik üzerinde hem biçimsel açıdan hem de içerik açısından köklü değişiklikler meydana getirdiği açıktır. Yeni medya ortamının sunduğu olanaklar; yeni medya gazeteciliği, çevrimiçi gazetecilik, dijital gazetecilik ya da internet gazeteciliği gibi birçok tanımlamanın literature girmesini sağlamıştır.

Çevrimiçi gazetecilik, "bağlamlı gazetecilik" olarak nitelendirilmekte ve bu tanımın iletişim yöntemlerinin genişliği, hiper medya, yüksek okuyucu kitlesinin katılımı, dinamik içerik ve uyarlama olmak üzere beş boyutu bulunmaktadır. Çevrimiçi gazetecilik ya da başka bir ifadeyle bağlamlı gazetecilik, "yeni medyadaki gelişmelerin okuyucu kitleyi daha bağlamlı ve seyredilebilir haber muhabirliğinde bir araya getiren yeni hikâye anlatım tekniklerinin gelişimini sağlamaktadır” (Pavlik, 2013, s. 7-41). Spence ve Quinn'e göre yeni medya haberciliği, "muazzam iletişim potansiyeliyle, modern bir haber toplama ve yayımlama biçimidir çünkü çok farklı katılımcının bağlanabildiği çevrimiçi bir forumdur” (2008, s. 264). Zannettou ve arkadaşlarına göre ise çevrimiçi ağlar, insanların bilgi iletimi ve kullanma yollarından birisi olarak önemli bir role sahiptir. Bunun başlıca nedeni, çevrimiçi ağların paylaşım ve bilgi edinimi için ideal bir ortam sağlamasıdır (2019, s. 1). Kalsın (2016, s. 77), yeni medyadaki gelişmelerle beraber izleyici katılımının mümkün hale geldiğine dikkat çekerek, bu durumun yeni tip gazetecilik modellerini beraberinde getirdiğine işaret etmektedir. Söz gelimi yeni medya gazeteciliği ana başlığı altında sosyal medya haberciliği, video haberciliği, mobil habercilik, yurttaş gazeteciliği, drone (uzaktan kumandalı insansız hava arac1) haberciliği, robot haberciliği ve veri gazeteciliği gibi alanlar yer almaktadır.

İnternet gazeteciliği, temel gazetecilik uygulamalarını her geçen gün değiştirmeye devam etmektedir. Haber içeriği üretmek, haber hikayesini farklı perspektiflerle sunmak, 
haberleri daha uzun süre arşivleyebilmek, haber okuyucuları ile daha aktif bir şekilde etkileşime geçebilmek gibi daha birçok yenilik gazetecilikle bütünleştirilmektedir (Van Der Haak, Parks, \& Castells, 2012, s. 2923; Geray \& Aydoğan, 2010, s. 310; Pavlik, 2013, s. 41). Bununla birlikte, internet gazeteciliğinin, gazetecilik uygulamalarına çok sayıda katkısı olsa da 21. yüzyılda gazeteciliği zorlayacak etkenler arasında insanların 'eksiksiz ve hızlı bilme' gereksinimi olduğundan söz edilmektedir (Demir \& Kalsın, 2015, s. 213). Deniz ve Korap Özel de yeni medya ortamının sunduğu olanaklar sayesinde, dijital gazeteciliğin geleneksel gazetecilikten yapısal olarak farklı özellikler gösterdiğine; hız, rekabet ve anındalık gibi unsurların haber üretim süreçlerini ve gazetecilerin farklılaşan çalışma koşullarını değiştirdiğine dikkat çekmektedir. Buna göre, gazeteciliğin temel amaçlarında önemli değişiklikler olmuştur. Söz gelimi geleneksel gazetecilik için kamunun bilgilendirilmesihaberdar edilmesi ve gazete tirajının yüksek olması temel bir hedef olarak görülürken, dijital gazetecilik için tıklanma ve dolayısıyla daha fazla reklâm almanın diğer amaçların önüne geçtiği düşünülmektedir (2018, s. 81). İnternet gazeteciliğinin üstesinden gelmek zorunda olduğu sorunlardan bir diğeri de haberde 'güvenirlik' meseledir. Nitekim internet gazeteciliği, yalnızca haberi daha hızlı iletme aceleciliği ile yanlış bilgilendirme yapmaz ayrıca daha çok reklâm alabilmek için kasıtlı bir biçimde etik açıdan sorun doğurabilecek tık odaklı habercilik gibi bazı yöntemlere başvurmaktadır (Dönmez, 2010, s. 106).

Yanlış bilgilerin yeni olmadığını ve kökeninin sansasyonel habercilik olarak bilinen "basılı gazete çağına" dayandığını ifade eden Zannettou ve arkadaşlarına göre, çevrimiçi ağların artması ile haber sitelerinde kasten yanıltıcı başlık ve ön izleme görseli kullanımı yani tık tuzağı habercilik anlayışı $\operatorname{artmıştır~(2019,~s.~3).~Benzer~şekilde~Chen,~Conroy~ve~Rubin~}$ (2015) de, geçmişten beri var olan haberlerin magazinleşmesinin ve dijital içerik üretme isteğinin tık odaklı haberciliği teşvik ettiğinin altını çizmiştir. $\mathrm{Bu}$ durum geleneksel gazetecilikte sansasyonel basını tanımlamak üzere yaygın bir şekilde kullanılan "sarı basın/gazetecilik" kavramsallaştırmasına ek olarak "dijital sarı basın/gazetecilik" kavramını gündeme getirmiştir (Potthast, ve diğerleri, 2018, s. 1499). Özyal, tık odaklı haberciliğin geleneksel gazeteciliğin sansasyonel habercilik anlayışından farklılık gösterdiğini çünkü sansasyonel bir olayı yakalamanın veya sıradan bir olayı sansasyonelleştirmenin tık odaklı haberciliğe göre daha fazla gazetecilik pratiği barındırdığını ifade etmektedir. Nitekim tık haberciliğinde ele alınan herhangi bir konu, güncel ya da önemli olmasa da belirli tekniklerle 
günün en çok okunan haberi olabilmektedir (2016, s. 299). Bu bakımdan Pavlik'in yeni medya ve etiğe ilişkin değerlendirmeleri oldukça dikkat çekicidir: "İnternetin ve dünya çapında ağın gelişmesi, yalnızca gazeteciliğin çevrimiçi olmasını sağlamakla kalmayıp, etik, karmaşık muammalara da ev sahipliği yapmıştır” (2013, s. 41).

\section{HABERCILIKK ANLAYIŞINDAKI DÖNÜŞÜMÜN BIR ÜRÜNÜ OLARAK TIK ODAKLI HABERCILIK}

Haber başlıkları haberlerin anlık görüntüleridir (Scacco \& Muddiman, 2016, s. 1). Haberlere kısa bir bakış açısı sağlayan ve özet olarak tanımlanan başlıklar; soru sorarak okuyucuda merak uyandırmak, okuyucuyu tahrik ederek reaksiyon almak, çoğu kez de okuyucunun ilgisini yakalamak üzere tasarlanmaktadır. Dijital dönüşümlerle beraber, çok sayıdaki haber kuruluşu dijital platformlara yönelmiştir. Habercilik alanında yaşanan bu dijital dönüşüm ise haber başlıklarını daha da önemli hale getirmiştir. Geleneksel gazetecilikte haber başlıkları hikâyeyi özetlediği için kritik bir yere sahiptir ve dijital dönüşümün bir ürünü olarak görülen 'tık haberciliği' kavramı bu çerçevede önem kazanmaktadır (Blom \& Hansen, 2015, s. 87-89).

Literatürde 'click-bait' olarak bilinen tık yemi/tık tuzağı kavramı, Cambridge sözlügünde "internette dikkat çekmek ve insanları belirli web sitelerinin linklerine tıklaması için teşvik eden makaleler, fotoğraflar” şeklinde tanımlanmaktadır (Cambrigde, 2019). Dijital gazetecilikte karşılaşılan etik sorunlar içerisinde anlam kazanan 'tık tuzağı' kavramı çok sayıda araştırmaya konu olmuştur (Blom \& Hansen, 2015; Scacco \& Muddiman, 2016; Biyani, Tsioutsiouliklis, \& Blackmer, 2016; Chakraborty, Paranjape, Kakarla, \& Ganguly, 2016; Zannettou, Sirivianos, Blackburn, \& Kourtelli, 2019). En genel anlamılla 'tık tuzağı' şeklinde hazırlanan haberlerde yer alan başlıklar, tıklanma sayısını artırmak amacıyla kurgulanmaktadır (Scacco \& Muddiman, 2016, s. 1). Chen, Conroy ve Rubin'e (2015) göre, tık tuzağı, şüpheli dil kullanımı, çözülmemiş zamirler, tersine dönük bir anlatım stili, ileriye atıf, görüntü yerleştirme ve önemli ipuçları verme gibi belirli dilsel kalıplar ile haberin inşa edilmesidir. Potthast ve arkadaşlarına göre ise (2018, s. 1499), haberde tık tuzağı kullanımı ile tıklanmak, dolayısıyla reklâm gelirlerini en üst seviyeye çıkarmak amaçlanmaktadır. Bu içeriklerle mümkün olduğunca daha fazla kişiyi cezbetmek ve meraklandırmak hedeflenmektedir. 
T1k haberciliği literatürde; 'kapan manşet' (Dönmez, 2010), ‘çöp haber' (Işık \& Koz, 2014), 'tuzak başl1k' (İnce, 2018) ve ‘tık odaklı haber sunumu' (Özyal, 2016) biçimlerinde adlandırılırken, bu çalışmalarda internet haberciliğinin etik açıdan sorunlu yanları da ortaya konmaktadır. Dönmez, 'kapan manşet' kavramını haber değeri varmış izlenimi uyandıran, haberde merak, endişe veya korku gibi duyguları harekete geçirmeyi hedefleyen fakat asıl amacın kullanıcıların sitede kalmasını sağlayan haber başlıklarını tanımlamak için kullanmaktadır (2010, s. 108). Işık ve Koz, 'çöp haber’ kavramı ile haber başlıklarının içerik ile uyumsuz olduğu ve reklâm gelirinden daha fazla pay alabilmek amacıyla kullanıcıların manipüle edildiği haber türlerine gönderme yapmaktadır (2009, s. 169; 2014, s. 36). Özyal ise haber başlıkları, görseller ve diğer multimedya unsurlarını da kapsayacak genel bir tanım olan ‘tık odaklı haber sunumları' kavramına başvurmuştur (2016, s. 275).

Sayısız haber seçeneğinin olduğu bir ortamda tık odaklı haber başlıkları, çeşitli oyunlarla dikkatleri üzerine çekmeye ve haber okuyucularının haber içeriğiyle ilgilenmelerini sağlamaya çalışmaktadır (Scacco \& Muddiman, 2016, s. 1). Tık odaklı habercilik anlayışında hedeflenen şey internet kullanıcılarının başlığa tıklamalarını sağlamak ve böylece açılan sayfayı paraya çevirmektir. Nitekim haber başlıkları hazırlanırken birebir yazı içeriğini yansitmak yerine kullanıcılarda merak, heyecan, cazibe uyandırma ve kimi zaman kullanıcıların sinirlerini bozarak onları tahrik etme gibi çeşitli stratejiler yoluyla haber başlıkları ilginç ve ilgi çekici hale getirilmektedir. Bu stratejiler yoluyla oluşturulan içerikler düşük kalitede olup haberin başlı̆̆ında vaat edilen içeriğin belirgin bir şekilde altında bir haber sunulmaktadır (Biyani, Tsioutsiouliklis, \& Blackmer, 2016, s. 94).

"Bu makaleyi okumalısınız" türü başlıkların tek başına anlamlı olmadığını fakat haber sitelerinde böyle başlıklara sıklıkla yer verildiğini belirten Blom ve Hansen’a göre, 'İleriye Gönderim' yani 'Forward Reference', okuyucuların başlığa tıklayıp haberi okumaları için beklenti ve merak uyandırması amaciyla kullanılmaktadır (2015, s. 87). Yine 'soru bazlı başlıklar' da yaygın bir biçimde kullanılmaktadır. Bu teknikte haberde yer alan ve dikkat çeken ayrıntıyla ilgili bir soru oluşturularak ya da belirsizlik yaratılarak haber kurgulanmaktadır. Okuyucu cevabı ancak hikâyenin geri kalanını tıkladığında bulmaktadır (Scacco \& Muddiman, 2016, s. 1). Biyani ve arkadaşları ise tık odaklı haber başlıklarının albenili olması için belli bir içerik tipi ve yazı formatı kullanıldığını belirtmektedir. 'En' ön ekli üstünlük sıfatlar ve zarflar, tırnak içindeki ifadeler, ünlemler, büyük harf kullanımı, soru sorma ve başka göstergeler tık 
odaklı haber başlıklarında sıklıkla kullanılmaktadır. Diğer taraftan tık odaklı haber başlıklarının çoğu yanıltıcı olup var olduğunu iddia ettiği haber açılan sayfanın metni arasındaki benzerlik daha azdir (2016, s. 95).

\subsection{Gazetecilik Etiği ve Tık Odaklı Habercilik}

Yanıltıcı haberler, gazeteciliğin her döneminde var olagelmiştir. Ne var ki dijital platformlar üzerinden 'para kazanma' ve 'haber paylaşma' firsatı bu sorunu daha kritik bir noktaya taşımıştır (Pangrazio, 2018, s. 7). Zannettou ve arkadaşları internet haber sitelerinin pek çoğunun popülarite ve para kazanma arayışı içerisinde olduğunu ve bunun için de kendi sitelerine yoğunluk sağlamak amaciyla yalan ve tık odaklı haberlere başvurmaktan geri durmadıklarını ifade etmektedir (2019, s. 5).

Bilindiği üzere, abonelik sistemi bulunmayan çevrimiçi yayıncıların temel gelir kaynakları reklâmlardır (Potthast, ve diğerleri, 2018, s. 1498; Vural \& Sütcü, 2019, s. 22). Tüm dünyada yaygın bir şekilde haber sitelerinin ana gelir kaynağının dijital reklâmlar olduğu gerçeğinden hareketle reklâm pastasından daha büyük pay almak rekabeti zorunlu kılmaktadır. Ayrıca internet sitelerinde çok sayıda çevrimiçi reklâmcılık modeli olsa da tıklama başına kazanç en yaygın fiyatlandırma modelidir ve bu model haber sitelerinin tık haberciliğine yönelmelerindeki önemli sebeplerden biri olarak görülmektedir (Beştaş \& Kırık, 2019, s. 85100). Çevrimiçi gazeteler, hem reklâm gelirlerinden daha fazla pay alabilmek hem de reklâm verenleri etkilemek amacıyla başta tık odaklı habercilik olmak üzere arama motoru haberciliği ve galeri/video haberciliğine yönelmiştir (Vural \& Sütcü, 2019, s. 22-23; Dönmez, 2010, s. 106).

Asıl amacın okunmaktan ziyade belli bir akış oluşturmak, tıklanmak ve böylece reklâm geliri elde etmek (Güzel \& Özmen, 2018, s. 225) olan habercilik düzleminde, haberciliğe dair temel sorumlulukların sorgulanması gereklidir. Tik haberciliği ile birlikte haber etiğinden uzaklaşılmakta ve kullanıcılar internet haberciliğini tam bir güvenilir kaynak olarak görmemektedir. Özellikle büyük çaptaki internet haber sitelerinin her an güncel haber verme isteği ve son dakika bilgileri hızla okuyucu ile paylaşma çabalarının tık haberciliğini artırdığını belirtmek gerekmektedir. Ayrıca haber başlıklarının ve içeriğin uyumsuzluğu okuyucuları büyük bir uçuruma itmektedir. Yapılan araştırmalar, internet haber sitelerinin tık odaklı habercilik anlayışı ile başlangıçta bir kazanç elde ettiğini ancak bu anlayışın zamanla büyük 
kayıplar doğuracağını ortaya koymaktadır (Beştaş \& Kırık, 2019, s. 100). Ayrıca tık odaklı haber içeriklerinin hem kullanıcı hem de yayıncılar açısından olumsuz özellikleri bulunmaktadır. İlk olarak tık odaklı haber içerikleri okuyucuların vaktini boşa harcamaktadır. Söz gelimi okuyucular ilgilerini çeken içeriği tıklayıp içi boş içerikle karşılaştıklarında hayal kırıklığına uğramaktadır. İkinci olarak tık odaklı habercilik anlayışı gazetecilik mesleğinin etik kurallarını ihlal etmekte ve haberi yayımlayan basın kuruluşunun da itibarını zedelemektedir. Son olarak sosyal medya ortamında paylaşılan bu tarz haber içerikleri her ne kadar haber sitesinin ziyaretçi sayısını artırsa da kalitesiz içeriklerin artmasını da beraberinde getirmektedir (Zhou, 2017). Ancak çoğu haber sitesi kar getirecek reklâm gelirlerine odaklanmış durumdadır ve kullanıcıların manipüle edilmesiyle ilgilenmemektedir (Zannettou, Sirivianos, Blackburn, \& Kourtelli, 2019, s. 5; Potthast, ve diğerleri, 2018, s. 1499). Bu bakımdan tık odaklı yaklaşımın kullanıcı deneyimi açısından ters yönlü bir etkiye sahip olduğunu söylemek yanlış olmaz çünkü kullanıcı ilgi duyduğu bir içeriği tıkladığında, başlıkta vaat edilen içerik ile gerçek içerik arasındaki farklılığı görmektedir. Söz konusu durum ise düşük kaliteli içeriklerin kullanıcı memnuniyetini düşürmesine ve siteyi terk etme oranını artmasına neden olmaktadır (Biyani, Tsioutsiouliklis, \& Blackmer, 2016, s. 94).

Chakraborty ve arkadaşları (2016, s. 9), okuyucu beklentilerini karşılamayan ve hayal kırıklığı yaratan tık odaklı başlıkları okuyucu lehine çevirmek üzere tıklamaları otomatik algılayan ve istenmeyen tıklamalara engel olmak üzere bir tarayıcı uzantısı geliştirmiştir. Benzer şekilde Biyani, Tsioutsiouliklis ve Blackmer da tık tuzaklarını tespit etmek amacıyla tık tuzaklarını otomatik olarak belirleyen öğrenen makine geliştirmiştir (2016, s. 99). Bu nedenle tık odaklı habercilik anlayışının, teknik bakımından birtakım önlemleri gerekli kıldığı açıtır. Diğer taraftan tık odaklı haber başlıkları ve sahte haberler ile mücadele edenler arasında Facebook, Snapchat ve Youtube bulunmaktadır. Fingas (2017), Snapchat uygulamasında, içerik ile bağlantısı olmayan, yalnızca tıklanmaya amaçlayan ve kullanıcıları yanlış yönlendiren başlıkların yasaklanması yönünde kurallar oluşturulduğunu ifade etmektedir. Buna göre, içerik sağlayıcılar içerik değeri olmayan başlıkları veya resimleri kullanamazlar ve sahte haber üretemez veya bunlara bağlantı veremezler. Amaç New York Times'da olduğu gibi "bilgilendirici, olgusal ve güvenli” bir alan yaratmaktır. 


\section{LITERATÜR İNCELEMESI}

Çevrimiçi haber platformlarının her geçen gün değişen ve gelişen yapısı, geleneksel gazetecilik uygulamalarının ve haberciliğe dair temel sorumlulukların sorgulanmasını beraberinde getirmiştir. Çevrimiçi ağların kar etmek amacıyla yaygın bir şekilde uyguladıkları tık odaklı haberciliği anlamak ve kavramak amacıyla çok sayıda akademik çalışma yapılmıştır. $\mathrm{Bu}$ çalışmalarda ele alınan konular; tık haberciliğinin gazetecilik faaliyetlerine etkisi, etik kuralların ihlali, tık odaklı haberciliğin okuyucu ve gazeteciler üzerindeki etkisi ve tık haberciliğini engelleyecek ya da tespit edecek bir takım otomatik yazılım modellerinin geliştirilmesidir.

Işı1k ve Koz (2009), “Cinsellik Üzerinden 'T1k Ticareti’: İnternet Haberciliği Üzerine Bir İnceleme" başlıklı çalışmada, adına "vagon haber" dedikleri haber uygulaması üzerinde durmaktadır. Bu çalışma, vagon haber içeriklerinin içerik bakımından zayıf olduğunu ve bu yöntemle okuyucunun tek bir haber için dakikalarca oyalandığını ayrıca mevcut uygulamanın tıklanma oranlarını artırdığını ortaya koymuştur. Çalışma doğrudan tık haberciliğine yönelik olmasa da tık ticaretinin ortaya çıkaracağı etik sorunlar üzerinde durulmaktadır. Dönmez (2010), “İnternet Haberciliğinde Tıklanma Kaygısı ve Kapan Manşetler” başlıklı çalışmada, farklı haber sitelerinden elde edilen haber örneklerini incelemiş ayrıca haber metni ve haber başlıkları arasındaki ilişkiyi sorgulamıştır. Çalışmada, internet gazeteciliğinde ticari kaygı sonucu haber başlıklarının yanıltıcı bir şekilde kurgulandığı ve tıklanan haber başlığı ile haberin kendisi arasında tam bir bütünlük olmadığı ortaya koyulmuştur. Işık ve Koz (2014) ise internet gazeteciliğinin önemli sorunlarından biri olarak görülen 'çöp site' ve 'çöp haber' kavramları üzerine yoğunlaşmışlardır. Türkiye'de yayın yapan internet haber sitelerinin örnek olaylar üzerinden incelendiği çalışmada, bu tür haber site ve haber içeriklerinin tek amacının daha fazla tık almak olduğu belirtilmiştir.

Blom ve Hansen (2015), çevrimiçi habercilikte ileri gönderim tekniğinin kullanımının bir çeşit haritasını çıkardıkları "Click bait: Forward- Reference as Lure in Online News Headlines" başlıklı araştırmada, Danimarka kaynaklı 10 farklı haber sitesinden derledikleri 100 bin haber başlığını çözümlemişlerdir. Çalışmadan elde edilen sonuçlara göre, çevrimiçi haber başlıklarında ileri gönderim tekniğine başka bir ifadeyle tık odaklı haber sunumlarına sıklıkla başvurulmasının sebebi çevrimiçi gazetecilikte temel gelir olan reklâmlardan daha fazla pay almaktır. Chen, Conroy ve Rubin (2015), tık haberciliği kavramına yönelik kavramsal 
tartışmalara yer verdikleri çalışmada, örnek haberler üzerinden tık kavramının ne olduğunu ortaya koymuştur. Araştırmacılara göre, yanlış bilgilendirmeyi tespit edecek otomatik bir model oluşturulmalı ve oluşturulan model okuryazarlığı desteklemek amaciyla okul ve kütüphanelerde de kullanılmalıdır.

Scacco ve Muddiman (2016), tık odaklı haber başlıklarının okuyucu üzerindeki etkisini araştırmışlardır. Çalışma kapsamında, haber kaynaklarının zaman içerisinde farklı başlık türleri ürettiği ve böylece yeni tıklamalar elde etmeyi amaçladıkları ortaya konmuştur. Biyani, Tsioutsiouliklis ve Blackmer (2016), tarafından gerçekleştirilen çalışmada ise araştırmacılar 8 adet tık tuzağı kategorisi oluşturarak tık tuzağı kavramına biçim kazandırmışlar ayrıca tık tuzaklarını otomatik olarak belirleyen makine geliştirerek alana katkı sunmuşlardır. Benzer şekilde Chakraborty ve arkadaşları da (2016), "Stop Clickbait: Detecting and Preventing Clickbaits in Online News Media" başlıklı çalışmada okuyucu beklentilerini karşılamayan ve hayal kırıklığı yaratan tık odaklı başlıkları okuyucu lehine çevirmek üzere tıklamaları otomatik algılayan ve istenmeyen tıklamalara engel olmak üzere bir tarayıcı uzantısı geliştirmişlerdir. Özyal (2016) ise tık odaklı habercilik anlayışını ve yeni medya etiğinin problemli sahasını incelemişstir. Bu çalışma hem tık odaklı haberciliğin etik açıdan değerlendirilmesi hem de tık odaklı haber sunumlarının örnekler üzerinden kategorilere ayrılarak tespit edilmesi bakımından önem taşımaktadır.

Pangrazio (2018), yalan haber, hakikat ötesi ve tık tuzağı çağında dijital okuryazarlıkta eleştirel düşünmeyi sağlayabilecek faktörleri ele aldığ1 çalışmada, bireylerin çevrimiçi haberlerle nasıl haşir neşir oldukları konusunda teknik, siyasi ve sosyal sorunları derinlemesine irdelemiştir. T1k odaklı haberlere "tık tuzağg” ismini veren İnce (2018), çalışmasında haber örnekleri üzerinden başlık ve haber metinleri arasındaki uyumu tespit etmiştir. İnce, tıklanma kaygısıyla haber içeriğinin yozlaştırıldığını ve okuyucuyu avlama amacıyla oluşturulan tuzak başlıkların bu yozlaşmaya öncülük ettiği sonucuna ulaşmıştır. Deniz ve Korap Özel (2018), Google odaklı habercilik anlayışı olarak bilinen SEO habercilik üzerine yaptıkları çalışmada, SEO haberciliğinin gazetecilik etiği açısından yarattığı sorunlar üzerinde durmuşlardır. Çalışma kapsamında, SEO haberlerinde karşılaşılan en önemli etik ihlallerden birinin tık odaklı habercilik olduğu sonucuna ulaşılmıştır.

Zannettou ve arkadaşları (2019), internet haberciliğinde karşılaşılan yanlış bilgi ekosistemi üzerine yaptıkları araştırmada, çevrimiçi haber siteleri tarafından yanlış 
bilgilendirme yapmanın ciddi problemler doğurabileceği üzerinde durmuştur. Yanlış bilgi ekosistemine yönelik genel değerlendirmelerin sunulduğu çalışmada, insan eli değmeden yapılan güncel otomatik çözümlerin internetteki yanlış bilgi problemlerinin etkisini başarılı bir şekilde azaltmayacağı sonucuna ulaşılmıştır.

Korap Özel ve Deniz (2019), internet gazeteciliğinin ortaya çıkardığı etik sorunları tespit etmeye yönelik araştırmada, 5 farklı internet haber sitesinden 15 gazeteci ile görüşmüşlerdir. Çalışmada, geleneksel gazeteciliğin hâlihazırdaki sorunlarına ek olarak dijitalleşen gazeteciliğin yeni etik ihlalleri beraberinde getirdiği ve okur açısından ortaya çıkan en büyük etik sorunlardan birinin tık odaklı haber başlıkları olduğu tespit edilmiştir. Kalender (2019) ise tık odaklı haberlerin ifşasına odaklanmıştır. Çalışmada Limon Haber isimli Twitter hesabını inceleyen Kalender, geleneksel medyada öteden beri var olan başlık sorunlarının dijital medyada da artarak devam ettiğini ortaya koymuştur. Beştaş ve Kırık (2019), tık haberciliği kavramını ekonomi politik yaklaşımla incelemiş, haber okurlarının yalan haber ve aşırı reklâmlardan rahatsız oldukları sonucuna varmışlardır. T1k haberciliğine bir alternatif olması bakımından haber sitesi aboneliğinin yaygınlaştırılması ve böylece haber sitelerinin sunmuş olduğu abonelik sistemi ile haber okurlarından alınacak aylık ve yıllık abonelik bedeli ile onlara reklâmsız haber sunulabileceği üzerinde durmuşlardır. Vural ve Sütcü (2019) tarafından yürütülen “Çevrimiçi Gazetelerde Ziyaretçi Trafiği ve Ziyaretçi Süresini Artırmaya Yönelik Metotlar" isimli çalışmada ise çevrimiçi gazetelerin tık odaklı habercilik başta olmak üzere bazı etik dışı uygulamalarla okuyucuyu nasıl manipüle ettikleri ve bu tekniklerin ne şekilde kullanıldığ1 ortaya konulmuştur.

\section{YÖNTEM VE İÇERIKK ANALIZIININ UYGULANMASI}

Türk internet haber medyasının tık odaklı haber üretimlerinin Twitter hesapları üzerinden ele alındığı alındığı araştırmada, En Son Haber, Hürriyet, Sözcü, Milliyet ve Yeni Akit'in 1 Haziran-10 Haziran 2020 tarihleri arasında paylaştı̆ğ tweet'ler içerik analizi ile incelenmiştir. Çalışmanın bu başlığı altında, araştırmanın modeli, evren ve örneklem, veri toplama teknikleri ile araştırma bulgularına yer verilmektedir.

\subsection{Araştırma Modeli}

$\mathrm{Bu}$ araştırmada tarama modeline dayalı içerik analizi uygulanmıştır. Sosyal bilimler alanında sıklıkla kullanılan içerik analizi, belirli kurallara dayalı kodlamalar ışığında metnin bazı sözcüklerinin daha küçük kategorilerle özetlendiği sistematik ve yinelenebilir bir tekniktir 
(Büyüköztürk, Kılıç Çakmak, Akgün, Karadeniz, \& Demirel, 2019, s. 259). İçerik analizinde uyaranların doğasını okuyucu veya dinleyiciye nesnel biçimde göstermek amaciyla içeriğe yönelik tanımlamalar yapılmaktadır (Berelson, 1952, s. 14). Böylece içerik analizinde ham veriler kodlanarak kategorilere ayrılmakta ve metin (veya diğer görsel, işitsel içerikler) analiz edilebilmektedir.

\subsection{Evren ve Örneklem}

Çalışma evreni Türk internet haber medyasıdır. Alexa verilerine göre 1 Haziran-10 Haziran 2020 tarihleri arasında Türkiye'de en fazla ziyaret edilen 5 haber sitesi sirasiyla En Son Haber, Hürriyet, Sözcü, Milliyet ve Yeni Akit’tir. Çalışma kapsamında 5 haber kuruluşunun Twitter hesapları incelemeye alınmıştır. Tüm hesaplar için toplam 9 bin 525 tweet ve retweet analiz edilmiştir.

Literatür taramalarından hareketle, tık odaklı haberciliği merkeze alan önceki araştırmaların her birinde haber siteleri üzerine odaklanıldığı görülmüştür. Bu araştırmada ise gazeteciliği hızlandıran, kısaltan ve mesajın interaktif bir şekilde ulaşmasını sağlayan ve kimi okurlar için internet ve basılı gazetelerden daha dinamik bir katkı sunan Twitter (Arık, 2013, s. 273-281) üzerinden tık odaklı haber yapma biçimleri tespit edilmeye çalışılmıştır.

\subsection{Veri Toplama Teknikleri}

Araştırmada; Biyani, Tsioutsiouliklis ve Blackmer (2016, s. 96) tarafından 8 kategoride ele alınan tık odaklı haber kategorileri kullanılmıştır. Bu kategoriler; Abartma, Merak uyandırma, Tahrik etme, Yazıyı biçimlendirme, Canlandırma, Sağ gösterip sol vurma, Belirsiz bırakma, Yanlış bilgi verme şeklinde sıralanmaktadır (bkz. Tablo 1).

\section{Tablo 1: Tık Tuză̆ı Tipleri}

\begin{tabular}{|c|c|}
\hline Türü & Tanımı \\
\hline Abartma & $\begin{array}{l}\text { Tiklandığında açılacak sayfanın içeriğini başlıkta abartılı şekilde } \\
\text { ifade etmek }\end{array}$ \\
\hline Merak Uyandırma & Başlıkta ayrıntılara yer vermeyerek merak uyandırmak \\
\hline Tahrik etme & $\begin{array}{l}\text { Uygunsuz/müstehcen sözcüklerle ifade etmek ya da bu tarz ifadeler } \\
\text { kullanmak }\end{array}$ \\
\hline $\begin{array}{l}\text { Yazıyı } \\
\text { biçimlendirme }\end{array}$ & $\begin{array}{l}\text { Büyük harf/ noktalama işareti kullanımında aşırıya kaçmak. } \\
\text { Özellikle TAMAMI BÜYÜK HARF ya da ünlem (!) işareti }\end{array}$ \\
\hline Canlandirma & $\begin{array}{l}\text { Konunun şehvet içeren, rahatsız edici ya da inanılması güç bir olay } \\
\text { șeklinde verilmesi }\end{array}$ \\
\hline $\begin{array}{l}\text { Sağ gösterip sol } \\
\text { vurma }\end{array}$ & $\begin{array}{l}\text { İçerikte olmayan şeyin başlıkta açıkça veya ima yoluyla ifade } \\
\text { edilmesi: Başlık ya tıklatır ya da atlanıp geçilir }\end{array}$ \\
\hline
\end{tabular}




\begin{tabular}{ll}
\cline { 2 - 2 } Belirsiz bırakma & $\begin{array}{l}\text { Merakı dürtmek maksadıyla başlık ya açık bir şekilde verilmez ya } \\
\text { da kafa karıştırıcı bir şekilde verilir }\end{array}$ \\
Yanlış bilgi verme & $\begin{array}{l}\text { Her yönüyle açıkça doğru olmayan bir yazı: Gerçekle } \\
\text { bağdaşmamakta. }\end{array}$ \\
\hline
\end{tabular}

Araştırma kapsamında kullanılan veriler, NodeXL programı kullanılarak ilgili haber sitelerinin Twitter sayfalarından elde edilmiştir. Faydalanılan bir diğer veri toplama aracı ise Twitonomy uygulamasıdır. Twitonomy ile daha önce belirlenen 5 haber sitesinin twitter hesapları; günlük paylaşılan ortalama tweet, takip edilen, takipçi, toplam tweet ve toplam ortalama retweet sayısı bakımından incelenmiştir.

Tablo 2: Haber Kuruluşlarının Twitter Hesap ve Paylaşım Bilgileri

\begin{tabular}{lccccc}
\hline Gazeteler & $\begin{array}{c}\text { Günlük } \\
\text { Ortalama } \\
\text { Tweet Say1s1 }\end{array}$ & Takip Edilen & Takipçi & $\begin{array}{c}\text { Toplam } \\
\text { Tweet }\end{array}$ & $\begin{array}{c}\text { Toplam } \\
\text { Ortalama } \\
\text { Retweets }\end{array}$ \\
\hline En Son Haber & 58,18 & 6 & 475,329 & 164,890 & 509 \\
Hürriyet & 200,19 & 39 & 4.292 .470 & 462.331 & 759 \\
Milliyet & 188,24 & 26 & 2.596 .062 & 403.831 & 414 \\
Sözcü & 242,70 & 30 & $2,512.855$ & 698.469 & 1,167 \\
Yeni Akit & 139,13 & 0 & 175.201 & 522.488 & 0 \\
\hline
\end{tabular}

Araştırmanın yürütüldüğü dönemde En Son Haber'in Twitter'da aktif olduğu günden itibaren 164 bin 890 tweet attığı, 475 bin 329 takipçiye sahip olduğu, 6 hesabı takip ettiği, günde ortalama 58,18 tweet attığ 1 ve günde 509 retweet aldığı anlaşılmaktadır. Hürriyet'in Twitter'da aktif olduğu günden itibaren 462 bin 331 tweet attığı, 4 milyon 292 bin 470 takipçiye sahip olduğu, 39 hesab1 takip ettiği, günde ortalama 200,19 tweet attığ1 ve günde 759 retweet aldığ1 görülmektedir. Milliyet'e bakıldığında, atılan toplam tweet sayısının 403 bin 831, takipçi sayısının 2 milyon 596 bin 062, 26 hesabı takip ettiği, günlük ortalama 188,24 tweet attığı ve günde 414 retweet aldığı kaydedilmiştir. Sözcü'nün ise Twitter' da aktif olduğu günden itibaren 698 bin 469 tweet attığı, 2 milyon 512 bin 855 takipçiye sahip olduğu, 30 hesabı takip ettiği, günde ortalama 242,70 tweet attığ1 ve günde 1,167 retweet aldığı görülmektedir. Son olarak Yeni Akit'in, atılan toplam tweet sayısının 522 bin 488, 175 bin 201 takipçiye sahip olduğu, hiçbir hesabı takip etmediği, günlük ortalama 139,13 tweet attığ1 aldığı ancak hiç retweet almadığı ortaya çıkmıştır.

$\mathrm{Bu}$ verilerden hareketle hem günlük ortalama tweet hem de toplam tweet sayıs bakımından Sözcü birinci sırada yer almaktadır. Hürriyet takipçi, takip edilen ve toplam 
ortalama retweet sayıları bakımından birinci sıradadır. Yeni Akit'in ise hiçbir hesabı takip etmediği ve retweet almadığg görülmektedir.

\subsection{Tık Odaklı Haber Sunum Örnekleri}

T1k odaklı haber sunumlarının hangi yöntem ve stratejilerle gerçekleştirildiğini ortaya koymak için haber örneklerine yer vermenin ve bu haberleri çözümlemenin önemli olduğu düşünülmektedir. Çalışmada, tık odaklı haber başlıklarının bir kısmının birden fazla kategoriye dahil edilebileceği görülse de kategorilendirme yapılırken başlıktaki en baskın kategori tercih edilmiştir.

\subsubsection{Abartma}

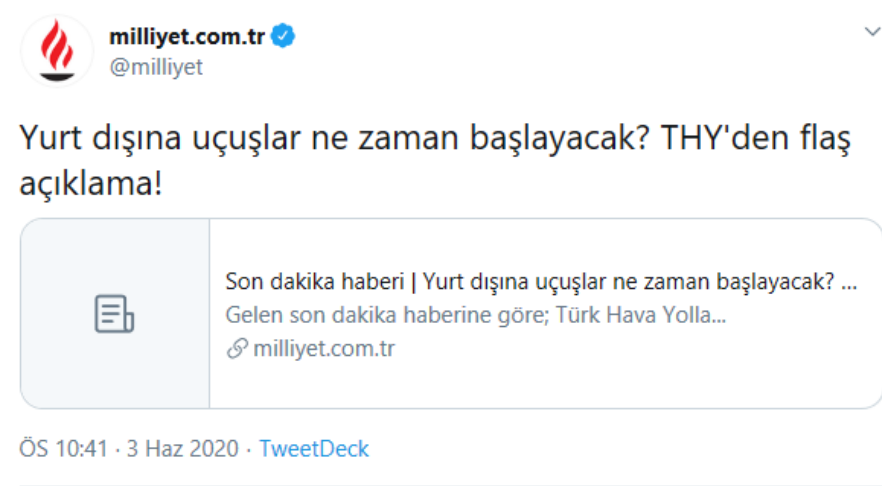

Fotoğraf 1: Abartma

Tık odaklı habercilik anlayışında en fazla kullanılan stratejilerden biri, tıklandığında açılacak sayfa içeriğinin başlıkta abartılı şekilde ifade edilmesidir. Bu tarz haberlerde, daha fazla tık almak amacıyla oldukça iddialı başlıklar tercih edilmektedir. Örnekte görüldüğü üzere, haberde 'flaş açıklama' ve 'son dakika haberi' ifadeleri ile haberin önemlilik derecesi artırılmaya çalışılmaktadır. Okuyucu, bu başlıktan hareketle yurt dışına uçuşlar konusunda yeni bir bilgiye ulaşacağını düşünmektedir. Ancak haberin detaylarına bakıldığında yurt dışına uçuşlar konusunda belirsizliğin devam ettiği ve asılında önemli bir gelişmenin olmadığı görülmektedir. $\mathrm{Bu}$ bakımdan haber içeriğinin başlıkta abartılı bir biçimde verildiği görülmektedir. Haber başlığı ve haber içeriği arasındaki uyumsuzlukların ise okuyucuların uzun vadede ilgili haber sitesine güvenini azaltacağı düşünülmektedir. 


\subsubsection{Merak Uyandırma}

$$
\text { (1) milliyet.com.tr } @ \text { milliyet }
$$

En çok aldatan burçlar belli oldu! mill.yt/56mw8

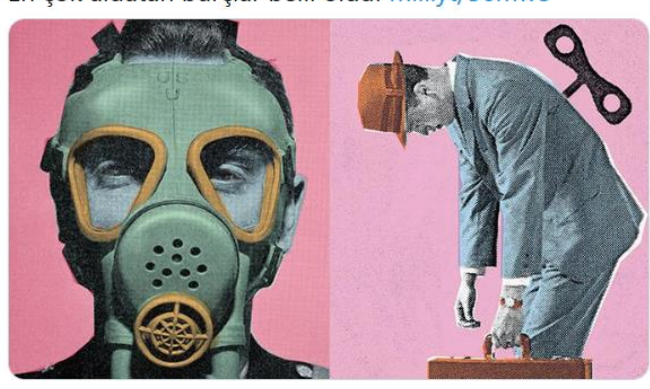

Ö 6:00 2 Haz 2020 - TweetDeck

3 Retweetler 6 Beğeniler

\section{Fotoğraf 2: Merak Uyandırma}

Kasıtlı bir biçimde ayrıntılara yer vermeyip merak uyandırmayı hedefleyen başlıklarda, okuyucu, sınırlı bir şekilde verilen haber başlığının ayrıntılarını öğrenmek için haber linkini tıklama gereksinimi hissetmektedir. Bu haber başlığından da anlaşılacağı üzere, en çok aldatan burcun hangisi olduğu açıklanmak yerine, "En çok aldatan burç belli oldu!" şeklinde genel bir ifade tercih edilmiştir. Ayrıca "belli oldu" ifadesi ile de 'yeni' bir şey açıklanıyor imajı yaratılmaktadır. Muhtemeldir ki başlıkta en fazla aldatan burcun hangisi olduğu açıkça belirtilseydi, okuyucuların daha az bir bölümü haberi tıklayacaktı. Özetle, heyecan ve merak uyandıran bir dil kullanımı, önemlilik atfedilmesi ve yenilik kazandırıldığı hissi verilmesi yoluyla okuyucuda tıklama eylemini harekete geçirmek hedeflenmektedir.

\subsubsection{Tahrik Etme}

Sözcü $\vee$

@gazetesozcu

Saba Tümer'den Ümit Karan'a şaşırtan soru! "Soyunma odasında donla mı..."

Saba Tümer'den Ümit Karan'a şaşırtan soru
Sunucu Saba Tümer, uzun yıllar Galatasaray forması giyen eski
futbolcu Ümit Karan'la Instagram'da canlı yayın yaptı.
S sozcu.com.tr

ÖÖ 9:54 · 4 Haz 2020 - Twitter Web App

Fotoğraf 3: Tahrik Etme 1 


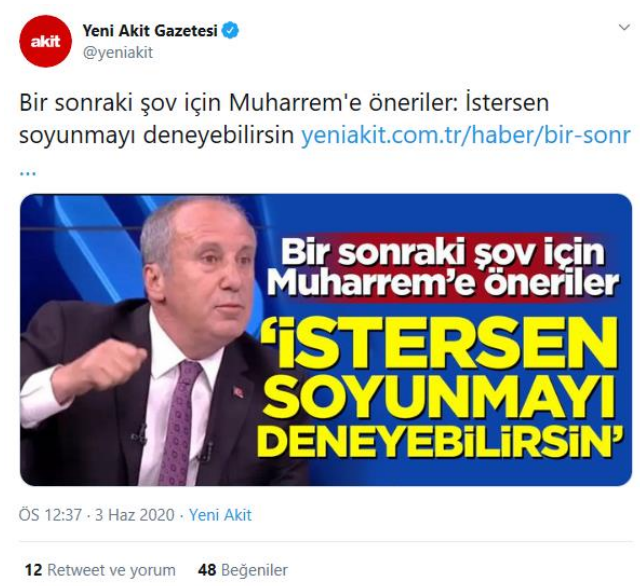

Fotoğraf 4: Tahrik Etme 2

Tık odaklı habercilik anlayışında kullanılan bir diğer strateji ise haber başlığında uygunsuz/müstehcen sözcüklere yer vererek veya bu çağrışımla okuyucunun ilgisini çekmeye çalışmaktır. Bu haberde ilk olarak “Saba Tümer'den Ümit Karan'a şaşırtan soru!” ifadesi ile okuyucunun merak duygusu harekete geçirilmektedir. Ardından "Soyunma odasına donla m1..." ifadesi ve belirsizliği pekiştiren üç nokta ise tam anlamıyla cinsel alana yönelik bir gönderme yapmaktadır. Diğer haberin öznesi ise siyasi bir kişilik olan Muharrem İnce'dir. "Bir sonraki şov için Muharrem'e öneriler: İstersen soyunmayı deneyebilirsin" başlıklı haberde ise siyasi bir tahrik söz konusudur. Her iki haberde de haber başlığının ana teması cinsellik üzerinden kurgulanmakta ve böylece cinselliğe yönelik merak dürtülerek daha fazla tık almak hedeflenmektedir. Diğer taraftan ikinci habere ilişkin başka bir etik sorun daha söz konusudur. Söz konusu haber başlığı, aslında gazeteci Engin Ardıç'ın bir yazısından alıntılandığı halde, tırnak içi ifade kullanılmamış ya da başlıkta Ardıç’a herhangi bir referans verilmemiştir.

\subsubsection{Yazıyı Biçimlendirme}

Ensonhaber.com $\otimes$

@ensonhaber

6 terörist BUMMM

\begin{tabular}{|l|l}
\hline Barış Pınarı bölgesinde 6 terörist öldürüldü \\
Bölgeye sızma girişiminde bulunan PKK/YPG'li 6 terörist, \\
komandolar tarafından etkisiz hale getirildi. \\
$\mathcal{S}$ ensonhaber.com
\end{tabular}

ÖÖ 10:27 · 2 Haz 2020 · Twitter Web App

Fotoğraf 5: Yazıyı Biçimlendirme 
T1k odaklı habercilikte kullanılan bir yöntem de haber başlıklarında büyük harf/noktalama işareti kullanımında aşırıya kaçmaktır. Haber örneğinden de anlaşılacağı gibi haber başlığında büyük harf kullanmak okuyucunun dikkatini çekmekte ve bu da okuyucunun haberi tıklamasını sağlamaktadır. $\mathrm{Bu}$ tekniğin genellikle içerikte önemli görülen şeyi güçlendirmek, vurgulamak ve öne çıkarmak üzere kullanıldığı söylenebilir. Araştırma kapsamında incelenen haber başlıklarında büyük harf, üç nokta ve ünlem işaretinin sıklıkla kullanıldığı görülmektedir.

\subsubsection{Canlandırma}

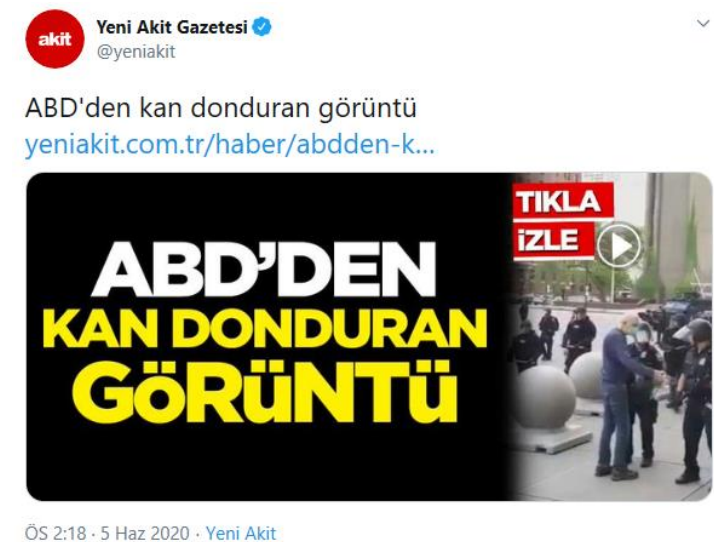

\section{Fotoğraf 6: Canlandırma}

Böylesi çarpıcı bir haber başlığı ile okuyucuda korkunç bir olayın gerçekleştiği izlenimi uyandırılmaya çalışılmaktadır. Haber başlığının inşasındaki temel vurgu okuyucunun "Kan donduran görüntü nedir?” sorusunu sormasını sağlamaktır. Haber başlığı 'inanılması güç bir olay’ şeklinde tasarlanmıștır. Buradaki asıl hedef okuyucuda merak, endișe ve kaygı gibi duyguları harekete geçirip haberi tıklattırmaktır. Diğer taraftan kullanılan görsel de haber başlığını tam olarak destekleyecek niteliktedir. Ayrıca, görselde kullanılan "tıkla izle" ifadesi tıklama eylemini harekete geçirmeyi hedeflemesi bakımından oldukça dikkat çekicidir. 


\subsubsection{Să̆ Gösterip Sol Vurma}

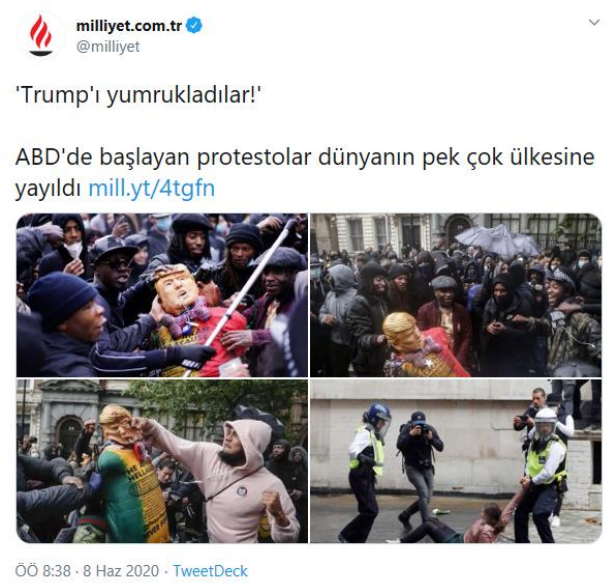

\section{Fotoğraf 7: Să̆ Gösterip Sol Vurma}

Kullanılan bir diğer strateji ise içerikte olmayan bir şeyin başlıkta açıkça ya da ima yoluyla ifade edilmesidir. Örnek haberde, 'Trump'1 yumrukladılar!' ABD'de başlayan protestolar dünyanın pek çok ülkesine yayıldı” ifadesine yer verilmektedir. Haberin hem görseline hem de detayına bakıldığında ise ABD Başkanı Donald Trump'ın kuklasının gösteriler sırasında yumruklandığ 1 ve tekmelendiği anlaşılmaktadır. Oysaki haber başlığındaki en temel vurgu Trump'ın 'yumruklandığı' algısı üzerine kurgulanmıştır. Nitekim içerikte olmayan bir şey başlıkta açıkça ifade edilerek okuyucunun haberi tıklaması sağlanmaktadır. Bu haber başlığı aslında yanlış bilgi verme kategorisine de dahil edilebilir ancak daha önce de ifade edildiği üzere kategorilendirme yapılırken başlıktaki en baskın kategori tercih edilmiştir. Ayrıca, haber linki tıklandığında, bu haberin bir 'son dakika' bilgisi olarak servis edilmesi de etik açıdan problemli görünmektedir.

\subsubsection{Belirsiz Bırakma}

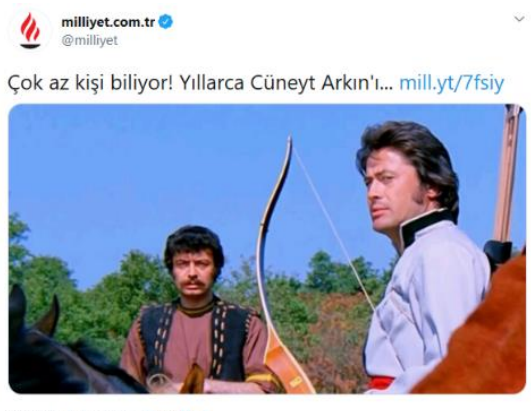

OS 4:25. 1 Haz 2020 - TweetDeck

Fotoğraf 8: Belirsiz Bırakma 
T1k odaklı haber sunumlarında, merakı dürtmek amacıyla başlığın açık bir şekilde verilmediği ya da kafa karıştırıcı bir şekilde verildiği sıklıkla görülmektedir. Bu haberde de "Çok az kişi biliyor" ifadesi ile adeta bir sır ya da esrarengiz bir bilgi paylaşılacağı algısı yaratılmaktadır. Yine, "Yıllarca Cüneyt Arkın'1...” ifadesi ile haber içeriğine dair herhangi bir ipucuna yer verilmeyip aksine haber tıklandığı takdirde özel-gizli-detay bilgilerin paylaşılacağı hissi uyandırılmaktadır. Söz konusu bu başlık, haberin içeriğini yansıtacak şekilde kurgulanmamıştır. Haber tıklandığında "Ünlü oyuncuları kimler seslendirdi? başlığı ile galeri haberciliği yapıldı̆̆ı görülmekte ve Cüneyt Arkın'1 seslendiren kişinin kim olduğu açıklanmaktadır. Bu tarz haberlerde okuyucuya hiç tahmin edilmeyen, bilinenin dışında, beklenmedik ya da şaşkınlık yaratacak bir bilgi verileceği izlenimi verilmekte ve okuyucunun haberi tıklaması sağlanmaktadır.

\subsubsection{Yanlış Bilgi Verme}

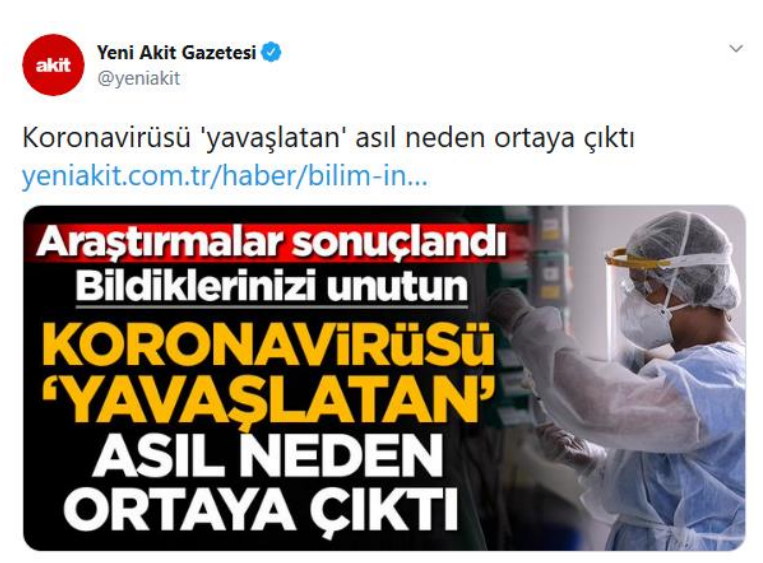

ÖÖ 8:03 · 3 Haz 2020 · Yeni Akit

\section{Fotoğraf 9: Yanlış Bilgi Verme}

Haber başlığı, okuyucuya haberi tıkladığında koronavirüsü yavaşlatan 'asıl nedene' ulaşacağı bilgisi vermektedir. Oysa haber metninde, Amerikalı araştırmacıların görüşlerinden hareketle hava sıcaklığı ve diğer hava koşullarının Kovid 19 salgının yayılmasını ne şekilde etkilediği üzerinde durulmaktadır. Kısacası haber içeriğinde koronavirüsü yavaşlatan 'asıl nedene' ilişkin herhangi bir bilgiye yer verilmemektedir. Burada okuyucu 'asıl neden', 'bildiklerinizi unutun', 'araştırmalar sonuçlandı' gibi net ifadelerle kasıtlı bir biçimde aldatılmaktadır. Bu durum ise insanların doğru bilgiye en fazla ihtiyaç duydukları kriz koşullarında dahi tık alma uğruna nasıl yanlış yönlendirilebildiklerini göstermektedir. Okuyucunun habere tıklamasını sağlamak üzere tasarlanan ve gerçekle bağdaşmayan haber başlıkları ile okuyucunun güven duygusu zedelenebilmektedir. Ayrıca bir başka etik problem 
de haberin Twitter' da 'Koronavirüsü 'yavaşlaşan' asıl neden ortaya çıktı” şeklinde net bir ifade ile verilmesi iken okuyucu haber linkini tıkladığında "Bilim insanları açıkladı: Koronavirüsü ‘yavaşlatan' koşullar bulundu!’’ ifadeleri ile sunulmasıdır.

\section{BULGULAR}

En Son Haber, Hürriyet, Sözcü, Milliyet ve Yeni Akit'in belirlenen tarihler arasındaki toplam tweet sayısı 9 bin 525'tir. İncelenen haberlerin tık odaklı haber olup olmadığına bakıldığında 3 bin 386 haberin tık odaklı olduğu, 6 bin 139 haberin ise tık odaklı olmadığ1 görülmektedir. Bu sayılar yüzdesel dağılım ile ifade edildiğinde incelenen haberlerin yüzde 35,5' lik bölümünde tık odaklı habercilik uygulamasının var olduğu; geri kalan yüzde 64,54'lük bölümde yer alan haberlerde ise tık odaklı haberciliğe ilişkin verilere ulaşılmadığı görülmüştür. Bu bakımdan yayımlanan her üç haberden birinin tık odaklı haber olduğu sonucuna ulaşmak mümkündür.

Tablo 3: Haberlerin tık odaklı olup olmadığına ilişkin dağılım

\begin{tabular}{lcc}
\hline Haberler & Frekans & Yüzde $(\%)$ \\
\hline T1k Odakli Haberler & 3386 & 35,55 \\
T1k Odakl1 Olmayan Haberler & 6139 & 64,45 \\
\hline Toplam & 9525 & 100 \\
\hline
\end{tabular}

5 haber kuruluşunun Twitter hesapları üzerinden tık odaklı haber sunumlarına yönelik değerlendirme yapıldığında, Yeni Akit yüzde 60,67 oranla tık odaklı haber sayısı bakımından en yüksek orana sahiptir. Elde edilen veriler 1şı̆̆ında Sözcü’nün yüzde 31,88, Hürriyet'in 29,58, En Son Haber' in yüzde 25,44, Milliyet' in ise yüzde 25,08 oranına sahip olduğu görülmektedir. Dikkat edildiği üzere her bir haber kuruluşunun tık odaklı haber sunum oranları birbirinden farklılık göstermektedir.

Tablo 4: Haber kuruluşuna göre tık odaklı haber oranları

\begin{tabular}{lccc}
\hline Gazeteler & $\begin{array}{c}\text { Toplam Haber } \\
\text { Say1s1 }\end{array}$ & $\begin{array}{c}\text { Tik Odaklı Haber } \\
\text { Say1s1 }\end{array}$ & Oran (\%) \\
\hline En Son Haber & 566 & 144 & 25,44 \\
Hürriyet & 1883 & 557 & 29,58 \\
Milliyet & 2317 & 581 & 25,08 \\
Sözcü & 2720 & 867 & 31,88 \\
Yeni Akit & 2039 & 1237 & 60,67 \\
\hline
\end{tabular}

T1k odaklı haberciliğin hangi strateji ve yöntemlerle gerçekleştirildiğini belirlemek amacıyla, çalışma kapsamında tespit edilen toplam 3386 tık odaklı haber önceden belirlenen 8 
kategoriye göre incelenmiştir. Elde edilen verilere göre, tık odaklı haber sunumlarında en fazla kullanılan kategori yüzde 38,07 oranla merak uyandırmadır. Bu kategoriyi sırasıyla yüzde 20,79 oranla belirsiz bırakma, yüzde 17,22 oranla abartma, yüzde 9,95 oranla tahrik etme, yüzde 7,83 oranla yazıyı biçimlendirme, yüzde 3,87 oranla canlandırma, yüzde 1,57 oranla sağ gösterip sol vurma ve yüzde 0,71 oranla yanlış bilgi verme takip etmektedir.

Tablo 5: Tık odaklı haberlerin kategorilere göre dağılımı

\begin{tabular}{lcc}
\hline Kategoriler & Frekans & Oran (\%) \\
\hline Abartma & 583 & 17,22 \\
Merak Uyandırma & 1289 & 38,07 \\
Tahrik Etme & 337 & 9,95 \\
Yazıyı Biçimlendirme & 265 & 7,83 \\
Canlandırma & 131 & 3,87 \\
Sağ Gösterip Sol Vurma & 53 & 1,57 \\
Belirsiz Bırakma & 704 & 20,79 \\
Yanlıș Bilgi Verme & 24 & 0,71 \\
\hline Toplam & 3386 & 100,00 \\
\hline
\end{tabular}

En Son Haber'de yer alan toplam 144 tık odaklı haberin kategorilere göre dağılımına bakıldığında, merak uyandırma kategorisinin yüzde 54,17 oranla birinci sırada olduğu görülmektedir. Yüzde 11,11 oranlarına sahip olan yazıyı biçimlendirme ve tahrik etme ikinci sırada yer almaktadır. Elde edilen verilere göre belirsiz bırakma yüzde 10,42, abartma yüzde 5,56, sağ gösterip sol vurma yüzde 4,17, canlandırma 3,37 oranına sahiptir.

Tablo 6: Tık odaklı haberlerin kategorilere göre dă̆ılımı (En Son Haber)

\begin{tabular}{lcc}
\hline Kategoriler & Frekans & Oran $(\%)$ \\
\hline Abartma & 8 & 5,56 \\
Merak Uyandırma & 78 & 54,17 \\
Tahrik Etme & 16 & 11,11 \\
Yazıyı Biçimlendirme & 16 & 11,11 \\
Canlandırma & 5 & 3,47 \\
Sağ Gösterip Sol Vurma & 6 & 4,17 \\
Belirsiz Bırakma & 15 & 10,42 \\
Yanlıș Bilgi Verme & - & 0,00 \\
Toplam & 144 & 100,00 \\
\hline
\end{tabular}

Hürriyet'te yer alan toplam 557 tık odaklı haberin kategorilere göre dağılımına bakıldığında merak uyandırma kategorisinin yüzde 38,24 oranla birinci sırada yer aldığı tespit edilmiştir. Diğer kategoriler sırasıyla şöyledir: belirsiz bırakma 28,55, abartma 17,59, tahrik 
etme 6,10 , canlandırma 4,49, yazıyı biçimlendirme 3,41, sağ gösterip sol vurma 1,26 ve yanlış bilgi verme yüzde 0,36 .

Tablo 7: Tik odaklı haberlerin kategorilere göre dağılımı (Hürriyet)

\begin{tabular}{lcc}
\hline Kategoriler & Frekans & Oran $(\%)$ \\
\hline Abartma & 98 & 17,59 \\
Merak Uyandırma & 213 & 38,24 \\
Tahrik Etme & 34 & 6,10 \\
Yazıyı Biçimlendirme & 19 & 3,41 \\
Canlandırma & 25 & 4,49 \\
Sağ Gösterip Sol Vurma & 7 & 1,26 \\
Belirsiz Birakma & 159 & 28,55 \\
Yanlıș Bilgi Verme & 2 & 0,36 \\
\hline Toplam & 557 & 100,00 \\
\hline
\end{tabular}

Milliyet'te toplam 581 tık odaklı haber bulunmaktadır. Tabloya göre merak uyandırma 52,67, belirsiz bırakma 16,52, abartma 16,35, tahrik etme 4,99, yazıyı biçimlendirme 4,65, canlandırma 3,44, sağ gösterip sol vurma 1,20 ve yanlış bilgi verme yüzde 0,17 oranına sahiptir.

Tablo 8: Tık odaklı haberlerin kategorilere göre dağılımı (Milliyet)

\begin{tabular}{lcc}
\hline Kategoriler & Frekans & Oran $(\%)$ \\
\hline Abartma & 95 & 16,35 \\
Merak Uyandırma & 306 & 52,67 \\
Tahrik Etme & 29 & 4,99 \\
Yazıyı Biçimlendirme & 27 & 4,65 \\
Canlandırma & 20 & 3,44 \\
Sağ Gösterip Sol Vurma & 7 & 1,20 \\
Belirsiz Bırakma & 96 & 16,52 \\
Yanlış Bilgi Verme & 1 & 0,17 \\
\hline Toplam & 581 & 100,00 \\
\hline
\end{tabular}

Sözcü'de yer alan toplam 867 tık odaklı haberin kategorilere göre dağılımına bakıldığında merak uyandırma 32,99, belirsiz bırakma 16,72, abartma 16,26, yazıyı biçimlendirme 15,69 , tahrik etme 12,11 , canlandırma 3,11 , sağ gösterip sol vurma 2,88 ve yanlıș bilgi verme yüzde 0,23 'tür. 
Tablo 9: Tık odaklı haberlerin kategorilere göre dă̆ılımı (Sözcü)

\begin{tabular}{lcc}
\hline Kategoriler & Frekans & Oran $(\%)$ \\
\hline Abartma & 141 & 16,26 \\
Merak Uyandırma & 286 & 32,99 \\
Tahrik Etme & 105 & 12,11 \\
Yazıyı Biçimlendirme & 136 & 15,69 \\
Canlandırma & 27 & 3,11 \\
Sağ Gösterip Sol Vurma & 25 & 2,88 \\
Belirsiz Birakma & 145 & 16,72 \\
Yanlış Bilgi Verme & 2 & 0,23 \\
\hline Toplam & 867 & 100,00 \\
\hline
\end{tabular}

Yeni Akit’te yer alan toplam 1237 tık odaklı haberin kategorilere göre dağılımına bakıldığında, merak uyandırma kategorisinin yüzde 32,82 oranla en fazla kullanıldığı tespit edilmiştir. En fazla kullanılan ikinci kategoride ise belirsiz bırakma yüzde 23,36 oranla yer almaktadır. Elde edilen verilere göre abartma yüzde 19,48, tahrik etme yüzde 12,37, yazıy1 biçimlendirme yüzde 5,42, canlandırma yüzde 4,37, yanlış bilgi verme yüzde 1,54 ve sağ gösterip sol vurma 0,65 oranına sahiptir.

Tablo 10: Tik odaklı haberlerin kategorilere göre dağılımı (Yeni Akit)

\begin{tabular}{lcc}
\hline Kategoriler & Frekans & Oran $(\%)$ \\
\hline Abartma & 241 & 19,48 \\
Merak Uyandırma & 406 & 32,82 \\
Tahrik Etme & 153 & 12,37 \\
Yazıyı Biçimlendirme & 67 & 5,42 \\
Canlandırma & 54 & 4,37 \\
Sağ Gösterip Sol Vurma & 8 & 0,65 \\
Belirsiz Birakma & 289 & 23,36 \\
Yanlıș Bilgi Verme & 19 & 1,54 \\
\hline Toplam & 1237 & 100,00 \\
\hline
\end{tabular}

Elde edilen verilere göre, yayımlanan her üç haberden birinin tık odaklı haber olduğu genellemesini yapmak mümkündür. Ayrıca 5 haber kuruluşu arasında en fazla tık odaklı habercilik yapan Yeni Akit’tir. Diğerlerinin sıralaması şöyledir: Sözcü, Hürriyet, En Son Haber ve Milliyet.

T1k odaklı haberlerin kategorilerine ilişkin bulgularına bakıldığında merak uyandırma kategorisinin ilk sırada yer aldığı görülmektedir. Bu kategoriyi sırasıyla belirsiz bırakma, abartma, tahrik etme, yazıyı biçimlendirme, canlandırma, sağ gösterip sol vurma ve yanlış bilgi verme takip etmektedir. Merak uyandırma, belirsiz bırakma ve abartma kategorilerinin 
Hürriyet, Milliyet, Sözcü ve Yeni Akit’te ilk üçte yer aldığg tespit edilmiştir. Burada 4 haber kuruluşunun ilk üç kategorideki sıralamaları aynı olsa da diğer kategori sıralamalarında farklılıklara sahip oldukları göze çarpmaktadır. En Son Haber'in kategorilere ilişkin bulguları ise merak uyandırma, yazıyı biçimlendirme ve tahrik etme şeklindedir. Buna göre haber kuruluşlarının yayın politikaları ve ideolojileri doğrultusunda farklı kategorileri kullandığı söylenebilir.

Yukarıda ifade edildiği üzere, tık odaklı haber kategorilerinden biri olan merak uyandırma 8 kategori arasında en fazla kullanılandır. Bu kategoride yer alan haberlerde, başlıklarda ayrıntıya yer verilmediği ve genellikle soru sorarak okuyucuda merak uyandırmanın hedeflendiği gözlemlenmiştir. Belirsiz bırakmada, başlığın açık bir şekilde verilmediği ya da kafa karıştırıcı bir şekilde verildiği; ayrıca habere ait en önemli detayın gizlendiği tespit edilmiştir. Abartma kategorisinde yer alan haberlerin genellikle "korkunç olay, bomba cevap, pes dedirten sözler, flaş karar-açıklama-mesaj-hamle, kritik uyarı-toplantı-zirve-karar, şoke etti, skandal görüntü, çarpıcı itiraf" ifadelerine yer verilerek gerçekleştirildiği ortaya konmuştur. Tahrik etme kategorisinde uygunsuz/müstehcen sözcüklere sıklıkla yer verildiği görülmüştür. Yazıyı biçimlendirmede ise okuyucunun habere ilgisini artırmak amacıyla haber başlığında büyük harf kullanımı veya noktalama işaretleri konusunda aşırıya kaçıldığı tespit edilmiştir. Canlandırmada, haber rahatsız edici ya da inanılması güç bir olay şeklinde verildiği saptanmıştır. Sağ gösterip sol vurma kategorisinde okuyucu genellikle kelime oyunları ile aldatılmaktadır ve içeride olmayan şey açıkça ya da ima yoluyla ifade edilmektedir. Son olarak her yönüyle açıkça doğru olamayan içeriklerin kasıtlı bir biçmde sunulduğu tespit edilmiştir.

\section{TARTIŞMA VE SONUÇ}

Haberin okunmasını sağlamak amacıyla başlığın iddialı, çarpıcı ya da ilgi çekici bir halde sunulması gibi uygulamalar, habercilikte yaygın bir şekilde kullanılmaktadır. Başlık ile haber içeriğinin birbiriyle paralel olması gazetecilik mesleği adına bir ideal değil önemli bir gerekliliktir. Ancak yeni medya ve gazetecilik alanında karşılaşılan etik sorunlar içerisinde anlam kazanan tık odaklı habercilikte, başlık ile haber içeriği arasında göz ardı edilmeyecek uyumsuzluklar söz konusudur. Bu araştırmada; daha fazla tık almak amacıyla oldukça iddialı başlıklar kullanıldığı, başlığın ‘inanılması güç bir olay’ şeklinde tasarlandığı, içerikte olmayan bir şeyin açıkça veya ima yoluyla ifade edildiği ve doğru olmayan bilginin okuyucuya sunulduğu görülmüş̧ür. Ayrıca kasıtlı bir biçimde ayrıntılara yer vermeyip merak uyandırmayı 
hedefleyen başlıkların sıklıkla kullanıldığı, başlıkta uygunsuz/müstehcen sözcüklere yer vererek okuyucunun ilgisini çekmeye çalışıldığı tespit edilmiştir.

Türk internet haber medyası üzerine odaklanılan bu çalışmanın en önemli yönü, yayımlanan her üç haberden birinin tık odaklı haber sunumu olduğunu ortaya koymasıdır. Çevrimiçi ortam, etkileşimi ve paylaşımı olanaklı kılan yapısı ile haberin kısa zamanda dolaşımını mümkün kılmaktadır. Dolayısıyla okuyucunun daha fazla kâr elde etmek uğruna manipüle edilmesi, bugüne özgü olmasa bile bu sorunu günümüz yeni medya eko-sistemi içerisinde kritik bir noktaya taşımaktadır. Haber siteleri tarafindan diğer haber sitelerinin önüne geçebilmek ve daha fazla kâr elde edebilmek adına kasıtlı biçimde üretilen yalan, aldatıcı, düşük kalitedeki içeriklerin üretim ve dağıtımının 'gazetecilik mesleği' adına gerçekleştiriliyor olması ise üzerinde durulması gereken bir başka önemli noktadır.

Haber örneklerine bakıldığında, tık odaklı haberciliğin küresel Kovid-19 salgını sürecinde bir strateji olarak yoğun bir biçimde uygulandığg görülmüştür. Toplum psikolojisi açısından zorlayıcı bir dönem olduğu kabul edilen böylesi bir süreçte, haber sitelerinin daha fazla tıklanma uğruna okuyucuları 'avlaması', korku ve paniğe neden olacak abartılı bir dil kullanması ve asılsız haber üretmesi düşündürücüdür. Nitekim insanların sağlıkları konusunda güvenilir ve doğru bilgiye en fazla ihtiyaç duydukları bir dönemde tık odaklı haberciliğin hız kazanması mevcut etik sorunları daha da kritik bir noktaya taşımaktadır.

İnternet gazeteciliğinde hali hazırda uygulanmaya devam eden reklâm politikalarına yönelik herhangi bir alternatif geliştirilmediği sürece tık odaklı haber sunumları haber siteleri tarafindan uygulanmaya devam edecektir. Bu durum uzun vadede hem okuyucunun haber sitesine duyduğu güveni azaltacak hem de haber kuruluşunun itibarını zedeleyecektir. Böylesi bir ortamda gerçekleştirilen gazetecilik faaliyetleri ise topluma karşı sorumluluk ve kamu bilinci ile hareket edebilme ideallerinden uzak olacaktır. Nitekim okuyucunun habere tıklamasını sağlamak üzere tasarlanan ve gerçekle bağdaşmayan haber başlıkları ile okuyucunun güven duygusu sömürülmekte ve doğru bilgiye ulaşmak giderek zorlaşmaktadır. $\mathrm{Bu}$ açıdan bugün daha çok yeni medya ve etik sorunlar içerisinde anlam kazanan 'tık odaklı habercilik' kavramının hukuki, teknik, ekonomi-politik açıdan değerlendirilmesi şarttır. 


\section{EXTENDED ABSTRACT}

Internet journalism continues to change basic journalism practices day by day. Many innovations such as producing news content, presenting the news story with different perspectives, being able to archive the news for a longer period, and being able to interact with newsreaders are integrated into basic journalism practices.

Digital journalism is structurally different from traditional journalism, thanks to the opportunities offered by new media. Factors such as speed, competition and instantness are changing the news production processes and the differing working conditions of journalists. Accordingly, there have been significant changes in the main goals of journalism. For example, for traditional journalism, public information and high newspaper circulation is a fundamental goal. For digital journalism, it is thought that clicking and therefore getting more ads outperform other purposes.

Internet journalism has specific problems. Reliability in news is one of these problems. Internet journalism deliberately uses some methods such as click-bait journalism that can pose ethical problems in order to get more ads. Click-bait journalism is named as 'trap headline', 'garbage news', and "click-based journalism". These concepts point to the ethically problematic aspects of internet journalism. For example, the concept of trap headlines is used to describe news headlines that give the impression of being newsworthy and that aim to activate emotions such as curiosity, anxiety or fear in the news. However, the main purpose of the trap headline is to keep users on the site.

The main purpose of click-based journalism is to create a certain flow and click rather than be read. Thus, more advertising income can be generated. In this form of reporting, primary liabilities need to be questioned. Click-bait journalism causes news organizations to move away from ethical values. For this reason, users do not see internet reporting as a fully reliable source. The structure of online news platforms is developing day by day. This has led to the questioning of traditional journalism practices and basic responsibilities regarding journalism. So any number of academic studies have been conducted to understand the click-bait journalism practices widely used by online news organizations to maximizing profit. Subjects deal with in these studies; the impact of click-bait journalism on journalistic activities, the violation of 
ethical rules, the effect of click-bait journalism on readers and journalists, and the development of automated software models that will detect click-bait journalism.

In this research, Twitter accounts examined in order to determine the click-bait news productions of Turkish internet news media. The tweets posted by En Son Haber, Hürriyet, Sözcü, Milliyet and Yeni Akit between June 1-10, 2020 were analyzed with content analysis. In the research, click-bait news categories in 8 categories by Biyani, Tsioutsiouliklis and Blackmer (2016: 96) were used. These categories are Exaggeration, Teasing, Inflammatory, Formatting, Graphic, Bait-and-switch, Ambiguous and Wrong.

9525 tweets were marked according to whether they were click-bait or not, and 3386 news items were found to be click-bait. Accordingly, it is understood that one out of every three news published is click-bait news. Yeni Akit is the most click-bait journalist among 5 news organizations. The others are listed as follows: Sözcü, Hürriyet, En Son Haber and Milliyet. When the categories of click-bait news are examined, the category of Teasing takes the first place. This category is followed by Ambiguous, Exaggeration, Inflammatory, Formatting, Graphic, Bait-and-switch, and Wrong. Teasing, Exaggeration and Ambiguous categories are in the top three in Hürriyet, Milliyet, Sözcü and Yeni Akit. Although the four news organizations have the same top three category rankings, the other category rankings are different. The top categories of En Son Haber are listed as Teasing, Formatting and Inflammatory. At this point, it is thought that news organizations use different categories due to their publishing policies and ideologies.

In the research, it was determined that shocking titles were used to get more clicks. Titles are designed as 'an unbelievable event' or something not in the content or incorrect information is presented to the readers as correct. In addition, titles that intentionally aim teasing by not including details are frequently used. The reader's attention is drawn with inappropriate/obscene words in the title.

The most important feature of this study focused on Turkish news media that is reveals one out of every three news are click-bait. The manipulation of the reader to make more profit makes this issue important for new media, although not unique to the present. Because, thanks to the structure of the online environment that enables interaction and sharing, news is put into circulation in a short time. It is noteworthy that the production and publishing of false, deceptive 
and low quality content produced in order to gain more profit is carried out on behalf of the ‘journalism profession'. 


\section{KAYNAKÇA}

Alexa. (2020). 06 01, 2020 tarihinde https://www.alexa.com/topsites/countries/TR adresinden alind1

Arık, E. (2013). Yurttaş gazeteciliğinin günümüzdeki görünümü: Twitter gazeteciliği örneği. Illetişim Kuram ve Araştırma Dergisi(36), 273-287.

Belsey, A., \& Chadwick, R. (2011). Medyada etik ve siyaset: Kalite arayış1. A. Belsey, \& R. Chadwick (Dü) içinde, Medya ve gazetecilikte etik sorunlar (s. 13-29). İstanbul: Ayrıntı Yayınları.

Berelson, B. (1952). Content analysis in communication research. New York: Hafner Press a Division of Macmillan Publishing Co. Inc.

Beştaş, C., \& Kırık, A. M. (2019). İnternet teknolojisi ile değişen haber konsepti: T1k haberciliğinin ekonomi politiği. N. Güngör (Dü.) içinde, Üsküdar üniversitesi iletişim fakültesi 6. uluslararası iletişim günleri dijital dönüşüm sempozyumu (s. 81-103). İstanbul.

Biyani, P., Tsioutsiouliklis, K., \& Blackmer, J. (2016). 8 amazing secrets for getting more cliks: Detecting clickbaits in nfews streams using article informality. Proceedings of the Thirtieth AAAI Conference on Artificial Intelligence (AAAI-16).

Blom, J. N., \& Hansen, K. R. (2015). Click bait: Forward-reference as lure in online news headlines. Journal of Pracmatics(76), 87-100 doi.org/10.1016/j.pragma.2014.11.010.

Büyüköztürk, Ş., Kılıç Çakmak, E., Akgün, Ö. E., Karadeniz, Ş., \& Demirel, F. (2019). Eğitimde bilimsel araştırma yöntemleri (26 Basım b.). Ankara: Pegem Akademi.

Cambrigde. (2019). Clickbait. Cambrigde Sözlük: https://dictionary.cambridge.org/tr/s\%C3\%B6zl \%C3\%BCk/ingilizce/clickbait adresinden alınmıştır

Chakraborty, A., Paranjape, B., Kakarla, S., \& Ganguly, N. (2016). Clickbait: Detecting and preventing clickbaits in online news media. 2016 IEEE/ACM International Conference on Advances in Social Networks Analysis and Mining (ASONAM) (s. 916). San Francisco: IEEE. CoRR abs/1610.09786.

Chen, Y., Conroy, N. J., \& Rubin, V. L. (tarih yok). Misleading online content recognizing clickbait as "false news". 17th ACM International Conference on Multimodal Interaction. Washington, DC.: DOI: 10.1145/2823465.2823467.

Demir, M., \& Kalsın, B. (2015). Yeni medya ve gazetecilik. Ankara Üniversitesi Illef Dergisi, 2(2), 209-214.

Deniz, Ş., \& Özel, E. K. (2018). Google gazeteciliği: Dijital çağda bir 'gerekli kötü' olarak SEO haberleri ve haberin 't1k' uğruna deformasyonu. Journal of Communication Sciences(55), 77-112. 
Dönmez, İ. H. (2010). İnternet haberciliğinde tıklanma kaygısı ve "kapan” manşetler. Akdeniz, Üniversitesi İletişim Fakültesi Dergisi(14), 105-128.

dx.doi.org/10.12739/NWSA.2014.9.2.4C0178. (2020).

Fingas, J. (2017). Snapchat Fights Clickbait in Discover Stories. 05 20, 2020 tarihinde https://www.engadget.com/2017-01-23-snapchat-fights-discover-clickbait adresinden alınd1

Geray, H., \& Aydoğan, A. (2010). Yeni İletişim teknolojileri ve etik. B. Çaplı, \& H. Tuncel (Dü). içinde Ankara: Fersa Yayınları.

Güzel, M., \& Özmen, K. (2018). Google tekelinde haberciliğin dönüşümü. Akdeniz, Üniversitesi İletişim Fakültesi Dergisi, (29), 206-229.

İnce, M. (2018). İnternet haberciliğinde çok tıklanma beklentisi ve tuzak başlıklar. Sosyal Bilimler Enstitüsü Karabük Üniversitesi, 8(2), 297-313.

Işık, U., \& Koz, K. A. (2009). Cinsellik üzerinden 'tık” ticareti: İnternet haberciliği üzerine bir inceleme. İletişim Kuram ve Araştırma Dergisi, (29), 167-188.

Işık, U., \& Koz, K. A. (2014). Çöp yığınlarında haber aramak: İnternet gazeteciliği üzerine bir araştırma. E-Journal of New World Sciences Academy, 9(2), 27-43.

Kalender, A. B. (2019). İnternet haberciliğinde clickbait savaşları: Bir okuyucu tepkisi olarak limon haber örneği. Adnan Menderes Üniversitesi Dördüncü Kuvvet Uluslararası Hakemli Dergisi, 2(2), 1-21. DOI: 10.33464/dorduncukuvvet.627074.

Kalsın, B. (2016). Geçmişten geleceğe İnternet gazeteciliği: Türkiye örneği. The Journal of Academik Social Science Studies, III(4), 75-94.

Korap Özel, E., \& Deniz, Ş. (2019). “T1k” ve “etik” arasında sıkışan gazetecilik: İnternet gazeteciliğinin ortaya çıkardığı yeni etik sorunlar ve gazetecilerin konuya bakış açısı üzerine bir araştırma. Erciyes Illetişim Dergisi, 6(1), 443-466.

Özyal, B. (2016). T1k odaklı habercilik: Tık odaklı haberciliğin Türk dijital gazetelerindeki kullanım biçimleri. Global Media Journal TR Edition, 6(12), 273-301.

Pangrazio, L. (2018). What's New abaout 'face news'?:Critical digital literacies in an era of fake news, post-truth and clickbait. Páginas de Educación, 11(1), 6-12. doi.org/10.22235/pe.v11i1.1551.

Pavlik, J. V. (2013). Yeni medya ve gazetecilik. (M. Demir, \& B. Kalsın, Çev.) Ankara: Phonix Yayınevi.

Potthast, M., Gollub, T., Komlossy, K., Schuster, S., Wiegmann, M., Patricia, E, Fernandez, G., Hagen, M., \& Stein, B. (2018). Crowdsourcing a large corpus of clickbait on twitter. Proceedings of the 27th International Conference on Computational Linguistics. New Mexico: Santa Fe. 
Scacco, J. S., \& Muddiman, A. (2016). Investigating the influence of "clickbait" news headlines. Center for Media Engagement, 1-12. https://mediaengagement.org/research/ clickbait-headlines/ .

Spence, E. H., \& Quinn, A. (2008). Information ethics as a guide for new media. Journal of Mass Media Ethics(23), 264-279. DOI: 10.1080/08900520802490889.

Van Der Haak, B., Parks, M., \& Castells, M. (2012). The future of journalism: Networked journalism. International Journal of Communication, 6, 2923-2938.

Van Dijk, J. (2004). Dijital media. J. Downing, D. McQuail, P. Schlesinger, \& W. Wartella (Dü) içinde, The sage handbook of media studies (s. 145-163). London: Sage.

Vural, N. E., \& Sütcü, C. (2019). Çevrimiçi gazetelerde ziyaretçi trafiği ve ziyaretçi süresini artırmaya yönelik metotlar. Ege Üniversitesi İletişim Fakültesi Yeni Düşünceler Hakemli E-Dergisi(11), 19-34.

Zannettou, S., Sirivianos, M., Blackburn, J., \& Kourtelli, N. (2019). The web of false İnformation: Rumors, fake news, hoaxes, clickbait, and various other shenanigans. Arxiv preprint arXiv:1804.03461, 1-26. DOI: 10.1145/3309699.

Zhou, Y. (2017). Clickbait detection in tweets using self-attentive network. https://arxiv.org/abs/1710.05364. 